\title{
Ugye in Hungarian: Towards a Unified Analysis
}

\author{
Beáta Gyuris
}

\begin{abstract}
The paper attempts to develop a unified approach to the conventional discourse effects of the Hungarian particle ugye as it occurs in assertions and question acts and presents a formal, dynamic semantic analysis of its contribution. It offers a sketch of a possible historical development from a tag-type use to a sentence internal use, through separation of the contribution of intonation from the contribution of the lexical meaning of ugye. The uniform contribution of ugye to assertions and questions in the synchronic stage is taken to be a contextual presupposition. It is proposed that ugye requires a prior commitment to the semantic content $\varphi$ of the sentence containing the particle on the part of the counterpart of the default perspective center of the speech act. In the case of an assertion it is the addressee who is argued to have a commitment to $\varphi$, which results in the "as you know" interpretation of ugye. In the case of questions it is the speaker who is presupposed to be committed to $\varphi$, which provides the biased question interpretation of sentences containing ugye pronounced with rise-fall intonation.
\end{abstract}

Keywords Assertion act - Question act • Tag • Bias • Presupposition

\section{The Distribution and Interpretation of Ugye: Basic Facts and Assumptions}

The current paper $^{1}$ takes a look at a puzzle concerning the particle ugye in Hungarian from a new perspective. As described in Gyuris (2009), this particle can make two different kinds of contributions to the meanings of sentences: it can

\footnotetext{
${ }^{1}$ I wish to thank the three anonymous reviewers of the paper for their valuable comments and suggestions, and Marcel den Dikken for editorial advice. Research for the paper was supported by the Alexander von Humboldt Foundation (under the Institutional Partnership Program) and the National Research, Development and Innovation Office-NKFIH, under project no. K 115922.
}

\section{B. Gyuris (四)}

Research Institute for Linguistics, Hungarian Academy of Sciences, Budapest, Hungary

e-mail: gyuris.beata@nytud.mta.hu 
appear in structures that are used to make question acts, as well as in those used to make assertions. The first use is illustrated in (1) below ${ }^{2,3}$ :

(1) Egy szép, kerek történetben reménykedik, ugye?

one beautiful round story.in hope.3sg UGYE

'You are hoping for a beautiful, round story, aren't you?' (HNC)

Sentence (1) minus ugye is an ordinary declarative, which can be used to assert that $\varphi$ (where $\varphi=$ ' $x$ hopes for a nice, round story', and $x$ denotes a contextually given individual, most probably the addressee). As far as the etymology of ugye is concerned, it came about by composing the demonstrative adverb úgy 'so' with the interrogative particle $-e$. As a default, sentence-final ugye in (1) bears a rise-fall pitch analogous to that of root polar interrogatives solely marked prosodically ${ }^{4}$ and is preceded by an intonational break. ${ }^{5}$ Thus, it can be taken to denote a polar question of the form? $\psi$, where $\psi$ is anaphoric to the most salient proposition in the context, i.e., $\varphi$.

In (1), the function of ugye seems to be analogous to that of tags in other languages: it attaches to an ordinary declarative, to form a structure that can be used to make question acts. As is well-known from the literature (Ladd 1981; Asher and Reese 2007; Reese 2007; Malamud and Stephenson 2015; Krifka 2017; Farkas and Roelofsen 2017), tag questions encode biased polar questions, which indicate that the speaker prefers one of the possible answers over the other. Claims to the same effect have been made for ugye-questions in Hungarian by Fónagy and Magdics (1967: 49), Károly (1962: 38), Kenesei et al. (1998: 3), and Varga (2002: 28), among others.

As the following examples show, in structures intended to encode questions, ugye does not necessarily have to appear sentence finally:

\footnotetext{
${ }^{2}$ In Hungarian, the third person singular form of the verb is used instead of the second person singular form if the subject refers to the addressee and the speaker wishes to address this person formally (i.e., using of the 'V-form').

${ }^{3}$ Hungarian National Corpus (http://corpus.nytud.hu/mnsz/index_eng.html, Oravecz et al. 2014). ${ }^{4}$ Ladd (1996) and Grice et al. (2000: 150) analyse the rise-fall pitch in terms of a L*HL\% contour. Cf. Kornai and Kálmán (1988), Mády and Szalontai (2014) and Varga (2002) for further discussion.

${ }^{5}$ Alternatively, sentence-final ugye, preceded by an intonational break, can also be pronounced with a falling tone $\left(\mathrm{H}^{*} \mathrm{~L}-\mathrm{L} \%\right)$. The function of the latter is to ask for confirmation rather than for agreement, and thus seems to have a function analogous to that of 'falling tag interrogative' in English (cf. Farkas and Roelofsen 2017). This falling questioning ugye, which cannot be integrated into the structure of the sentence, will not be discussed further in this paper.
} 
(2) Abban reménykedik, ugye, hogy mindent szépen elmesélek? that.in hope.3sG UGYE that everything.ACC nicely vM. tell.1sG 'You are hoping that I will tell you everything, aren't you?' (HNC)

(3) Befejezed ugye az egyetemet? finish.2SG UGYE the university.ACC 'You are going to finish university, aren't you?' (HNC)

(4) Ugye ezt most nem gondoltad komolyan? UGYE this.ACC now not thought.2sG seriously

'You aren't serious, are you?' (HNC)

The use versus lack of commas around ugye reflects the intended degree of prosodic integration of the particle. As Gyuris's (2009) recordings indicate, non-final occurrences of ugye in sentences that are used to make question acts are also pronounced with a rise-fall pitch, although of a smaller amplitude than the sentence-final variants, and sentences intended as questions with non-final ugye do not have a final rise-fall pitch. For these reasons, uses of the particle contributing to forms encoding question acts will be referred to as ugye $\bigwedge$. Gyuris (2009) argues against considering forms with sentence-internal ugye $\Lambda$ as representatives of the interrogative sentence type, as suggested by some authors in the Hungarian literature (H. Molnár 1968; Keszler 2000; Kugler 1998) on the basis of their incompatibility with negative polarity items, and the impossibility of embedding them under verbs that normally embed interrogatives. Since ugye $\wedge$ is also incompatible with the interrogative particle $-e$ and the final rise-fall pitch, formal indicators of the interrogative sentence type, we will in what follows avoid referring to forms containing ugye $\Lambda$ as interrogatives. They are more adequately described as declaratives containing internalized 'tags', which can be used to make question acts.

As mentioned above, ugye can also appear in sentences that are used to make assertions. Relevant examples include $w h$-interrogatives with a rhetorical question interpretation, as in (5), and ordinary matrix declaratives, as in (6):

(5) A vereséget meg ugye ki szereti?

the defeat however UGYE who like.3sg

'After all, who likes defeat?' (HNC)

(6) És függöny nélkül ugye nem lehet. and curtain without UGYE not possible

'It is not possible without a curtain, as we know.' (HNC)

Moreover, as (7) illustrates, ugye can also appear in embedded declaratives, which indicates that it is not restricted to forms available for making assertions, but is compatible with all declarative forms, independently of whether they are embedded or unembedded: 


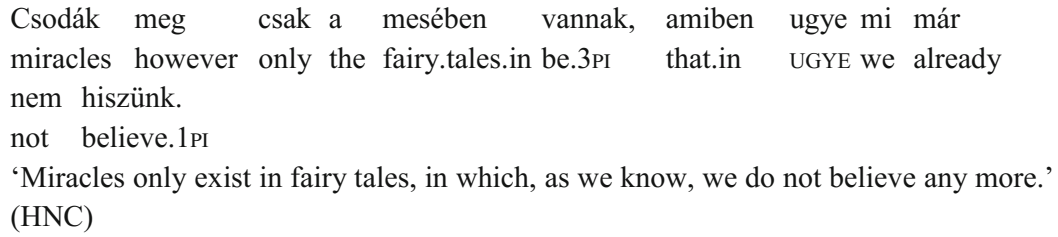

In (5)-(7), ugye is integrated into the prosody of ordinary declaratives, and does not bear any additional marking. For this reason, the occurrences of the particle in declaratives and other forms expressing assertions will be referred to as ugye (prosodically integrated ugye). Gyuris (2009) argues that the interpretation of ugye $\sim$ shows close similarities to that of particles that are claimed to mark that the proposition denoted by the rest of the sentence is part of the Common Ground (CG) according to the speaker, such as German ja (Zimmermann 2011). ${ }^{6}$ Based on a detailed comparison of the behaviour of ja and ugye , Gyuris (2009) suggests that the contribution of the latter to the interpretation of Hungarian declarative sentences is to mark that, according to the speaker, the propositional content of the sentence follows, due to default reasoning, from the CG.

Regarding ugye , Molnár (2016) provides new data ${ }^{7}$ illustrating that it can not only appear in rhetorical questions, but also in information questions encoded by $w h$-interrogatives, as in (8):

$$
\begin{aligned}
& \text { És ez a kicsi itt mi ugye, ez micsoda? } \\
& \text { and this the small here what UGYE this what }
\end{aligned}
$$
'And this small one here, what is this again?'

Regarding the interpretation of wh-interrogatives with ugye , used as information questions, Molnár (2016) argues that the contribution of the particle can be modelled by extending the proposal Gyuris (2009) makes for declaratives. Thus, in addition to marking that a proposition corresponding to one of the possible answers to the $w h$-question is in the CG, ugye in a $w h$-interrogative $I$ can also indicate that the question encoded by $I$, or a different one whose answer entails the answer to $I$ has already been asked in the conversation. In what follows, we will focus on more prototypical occurrences, and thus restrict our investigations to ugye appearing in declaratives.

The occurrence of ugye in declaratives is quite pervasive in contemporary Hungarian, in spite of heavy attack by normative linguists. As argued in Benkő (1995), the first appearance of the latter use was attested in 1923. This suggests that an integrated theory of ugye should be able to explain the process in the course of

\footnotetext{
${ }^{6}$ It was Péteri (2002) who first noted the similarities between ugye and ja referred to above.

${ }^{7}$ The source of Molnár's (2016) data is the BUSZI-2 database (http://buszi.nytud.hu).
} 
which the interpretation associated with ugye came about from the interpretation of the particle in constructions that are used to encode questions, which has a considerably longer history, going back to the 16th century. Gyuris (2009) provided independent accounts of the interpretations of ugye $\wedge$ and ugye, but did not succeed in offering an explanation for how the two interpretations are related, and how the chronologically second, context-marking use of the particle came about. This paper is an attempt at providing a formal theory of the two interpretations of the particle and modeling the meaning change that resulted in the current interpretation of ugye ${ }^{8}$

\section{Towards Unifying the Two Meanings of Ugye: Informal Analysis}

The rest of the paper will show that the contemporary interpretation of ugye can be formalized in such a way that, on the one hand, it reflects the historical developments, and, on the other hand, it considers the contributions of the two prosodic variants as similar as possible.

We propose that ugye came about as a result of a five-stage development. First, ugye started out as a final tag, with a transparent morphology, attached to a declarative. In the course of describing its contribution, we will most closely follow the suggestions by Krifka (2017: 388) regarding the interpretation of tag questions in English. He assumes that these constructions express, on the one hand, the speaker's commitment to the propositional content $\varphi$ of the declarative, and, on the other hand, that there are two possible continuations of the discourse after the tag question has been uttered. In one of them, $\varphi$ becomes part of the $\mathrm{CG}$, and in the other one, the addressee commits himself to $\neg \varphi$. Note that the contribution of the declarative clause component, described above, differs from the contribution of root declaratives that are used to make ordinary assertions, which express two commitments. The first is the commitment by the speaker to stand behind the proposition $\varphi$, encoded by the declarative clause syntax, and the second is the commitment that the asserted proposition $\varphi$ should become part of the common ground, encoded by the prosody (the nuclear stress $\mathrm{H}^{*}$ ) (p. 371). ${ }^{9}$ Based on these ideas, we will assume that questions with ugye express that the speaker is committed to $\varphi$, and ask the addressee whether he is committed to $\varphi$ or $\neg \varphi$.

In the second stage of its development, ugye lost its morphological transparency, and the fact that it was used to encode a question was marked by the fall-rise

\footnotetext{
${ }^{8}$ Recent empirical and theoretical studies of ugye include Abuczki (2015), Schirm (2011) and Kleiber and Alberti (2014). None of them offers a comprehensive account of the various uses of ugye in questions and assertions, however.

${ }^{9}$ Cf. also Gunlogson (2003) and Farkas and Bruce (2010) for assumptions on commitments associated with assertions and questions.
} 
melody. Note that postulating this change is necessary in order to explain the current distribution of ugye in forms that are used to make question acts, following the assumptions made in Gyuris (2017) on interpretational differences between polar interrogatives marked by the $-e$ particle and those marked by the final rise-fall melody in Hungarian. According to these, the particle $-e$ is only compatible with contexts where the truth of neither of the possible answers follows on the basis of evidence that recently became available to the interlocutors, whereas the forms with the rise-fall melody are also acceptable if the available evidence indicates the truth of the positive answer (i.e. the answer with the same propositional content as the interrogative). The fact that question acts made with a sentence containing ugye $\wedge$ are compatible with situations where the evidence alone forces the positive answer to be true supports this claim. The syntactic configuration characteristic of stage two is the same as the one illustrated in the contemporary example (1) above, repeated in $(9),{ }^{10}$ :

Egy szép, kerek történetben reménykedik, ugye?

one beautiful round story.in hope.3sg UGYE

'You are hoping for a beautiful, round story, aren't you?' (HNC)

In the third stage, ugye $\wedge$ became an internalized (i.e. non-final) tag, illustrated in (3)-(4), the former of which is repeated in (10):

(10) Befejezed ugye az egyetemet?

finish.2sG UGYE the university.ACC

'You are going to finish university, aren't you?'

The interpretation of (10) is analogous to tag questions with final ugye, discussed above. This means that in (10), ugye $\wedge$ still encodes the speaker's commitment to the proposition $\varphi$, expressed by the rest of the sentence. This commitment is not part of atissue content (Tonhauser et al. 2013) but a condition on input contexts, referred to as a contextual presupposition (Davis 2009) or as a use-condition (Gutzmann 2015). This accounts for the fact that if the addressee gives a negative answer to (10), it simply means that (s) he does not intend to finish university, but it leaves intact the speaker's public commitment to the opposite. Since a negative answer by the addressee means that he does not share the public commitment of the speaker to $\varphi$, the latter proposition will not become part of CG, as expected. ${ }^{11}$ The following constructed example (that corresponds to a famous example by Gunlogson 2003, 2008) illustrates that questions with ugye are infelicitous when speaker bias is not wished for:

\footnotetext{
${ }^{10}$ Hungarian National Corpus (http://corpus.nytud.hu/mnsz/index_eng.html, Oravecz et al. 2014).

${ }^{11}$ According to Gunlogson (2003) and Farkas and Bruce (2010), if interlocutors share a public commitment to a proposition $\varphi$, this becomes part of the CG.
} 
(11) [Context: A is conducting a committee hearing. A turns to B.]

A: \#Maga ugye kommunista?

you ugye communist

\#'You are a communist, aren't you?'

Recent work on the interpretation of tag questions suggests that it might be too strong to require that the speaker be fully committed to the propositional content $\varphi$ of an ugye $\wedge$-question. Malamud and Stephenson (2015) argue, for example, that the contribution of reverse polarity tags in English can be modelled by saying that they introduce a projected (delayed) commitment, which only becomes an actual commitment if the hearer agrees. ${ }^{12}$ The reason why I do not think that this would be an optimal solution for ugye $\wedge$-questions is that after asserting a question like (10), the speaker can rightfully be criticized for assuming the propositional content $\varphi$, even if the addressee provides a negative answer. Farkas and Roelofsen (2017) propose a different approach, according to which rising and falling tag interrogatives indicate that the speaker has access to some evidence for the truth of $\varphi$. Due to space limitations, I cannot offer a proper discussion of the above framework with respect to the Hungarian data. It seems to me, however, that the use of ugye $\wedge$ in questions does not require that the speaker have evidence for the truth of the propositional content, her commitment can be based on her expectations or wishes as well. ${ }^{13}$

Continuing with the hypothetical historical development of ugye, we come to the fourth stage, which has not been discussed before in the literature. This makes it the central part of the proposal. I want to suggest that in this stage ugye $\wedge$ underwent semantic reanalysis. This means that the components of the interpretation of sentences containing ugye $\wedge$ were redistributed among the structural units, namely, the declarative clause, the particle ugye and the rise-fall intonation of ugye, in a way that in the fifth stage, ugye could make a contribution to the meaning of declaratives by itself, independently of its intonation. ${ }^{14}$ Intuitively, the division of labour looks as follows: the sentence minus ugye $\Lambda$ is responsible for encoding the propositional content, the rise-fall intonation on ugye enables the sentence to be used in making question acts, and the lexical meaning of ugye itself contributes the rest. In order to

\footnotetext{
${ }^{12}$ In Malamud and Stephenson's (2015: 291) words, "when using an RP-tag, a speaker is not directly committing to $p$, but is indicating that if $p$ is confirmed, she will share responsibility for it". ${ }^{13}$ In case we were to adopt Farkas and Roelofsen's (2017) approach for the analysis of ugye $\Lambda$, the question would arise whether we should consider it similar to rising tags and attribute to it a 'credence' level between moderate to high, or similar to falling tags, and attribute to it a high 'credence' level, given that the Hungarian construction is available both for asking for confirmation and for asking for acknowledgement.

${ }^{14}$ For a discussion of the process of semantic reanalysis, cf. Eckardt (2006).
} 
see how exactly this rest should be described, let us consider what happens in the fifth stage of the development.

In the final stage five, ugye loses its prosodic marking. As a result, the speech act type encoded by the sentence will be one associated with a declarative as a default, namely, an assertion. What ugye contributes to these assertions, following Gyuris (2009), is the introduction of the contextual presupposition or use-condition that the speaker considers the propositional content $\varphi$ of the rest of the sentence to be part of the CG, in other words, a joint commitment of the speaker and the addressee. This proposal accounts for the fact that the propositional content of a declarative with ugye is identical to the propositional content of the same declarative without the particle. In the case of (6), repeated in (12), the proposal would work as follows:

(12) És függöny nélkül ugye nem lehet. and curtain without UGYE not possible 'It is not possible without a curtain, as we know.'

The speaker of (12) expresses a commitment to the truth of the proposition $\varphi=$ 'it is not possible without a curtain', presupposing that the latter is a joint commitment of herself and the addressee. The following, constructed example shows that whenever the context is incompatible with such a joint commitment, ugye is infelicitous in an assertion:

[Context: A, an elderly woman, has just hung up the phone, and turns to her husband:]

A: Megszületett (\# ugye) az unokánk.

vM.be.born UGYE the grandchild.our

'Our grandchild has been born, (\#as we know).'

It might appear that the presupposition attributed to ugye above is too strong, since it can also be used in conversations where the addressee had not made any utterance that publicly committed him to the propositional content $\varphi$ of the declarative. I believe that in such cases the utterance of an ugye-declarative amounts to accommodating the presupposition described above. This is supported by the fact that whenever the addressee does not want his commitment to $\varphi$ be recorded, he explicitly has to protest against it. ${ }^{15}$

\footnotetext{
${ }^{15}$ I thank one of the anonymous reviewers of the paper for asking for clarification in this matter. I believe, however that the solution proposed by the reviewer herself/himself, according to which the use of ugye "requires the Speaker to have some evidence (private or public) that the Addressee will go along with her commitment" is too weak, since it would predict that Addressee's agreement depends on how successfully Speaker can convince him that she has evidence (not shared by Addressee) for the truth of $\varphi$. For example, although in the situation illustrated in (13), the husband seems to have every reason to go along with the speaker's commitment (assuming that she has just spoke to a person who has first-hand information about the birth of the child), the use of ugye is still infelicitous.
} 
Let us consider what would happen if we assumed that ugye makes the same contribution to questions like (10) that it makes to assertions like (12), described above. In this case, we would have to assume that (10) is used to make question acts asking whether $\varphi=$ 'addressee finishes university' is true, which are felicitous in contexts where the speaker considers $\varphi$ a joint commitment of the speaker and the addressee. This characterization, however, is on the wrong track, since (10) is perfectly fine in contexts where the speaker does not assume that the addressee is committed to $\varphi$, although it is infelicitous when the speaker is not committed to it.

It was proposed above that (12) and its kin presuppose that both speaker and addressee are committed to the propositional content $\varphi$. Since, however, the sentence is used to assert the very same proposition, which is only possible if the speaker is committed to it, the felicity conditions of assertions with ugye are also correctly expressed by saying that the addressee is committed to the propositional content.

These observations boil down to the following. If the meaning of ugye is considered independently of its intonation, it seems to introduce two different kinds of presuppositions in questions and assertions. In the former case, the contextual presupposition appears to be that the speaker is committed to the propositional content of the question, and in assertions it appears to be that the addressee is committed to the latter.

The above results indicate a similarity of ugye to discourse particles whose semantic effect depends on the sentence type they appear in or the speech act type they encode. One of the best-known of these is German wohl, which expresses uncertainty of the speaker in assertions and uncertainty of the addressee in questions. The effect is attributed in the literature to the fact that the two types of speech acts differ as to which participant serves as the epistemic reference point, also referred to as epistemic judge (Lasersohn 2005; Stephenson 2007), or perspective center (Bylinina et al. 2014), that is, the person "relative to whose knowledge base the whole sentence is evaluated" (Zimmermann 2011). The phenomenon is often referred to informally as the "interrogative flip".

What is interesting about the behaviour of ugye, as compared to the other expressions whose interpretation relies on the perspective center is that it does not attribute a belief to the participant identical to the perspective center but to the interlocutor of that participant. Thus, in questions it encodes the attribution of a commitment to the speaker, and in assertions the attribution of a belief to the addressee, by the speaker.

\section{Formalization}

In the course of formalizing the proposal outlined in the previous section we will follow the assumptions of dynamic semantics, according to which the utterance of sentences changes certain parameters of the context. Therefore, we will assign the sentences under consideration a context-change potential (CCP), which reflects the 
properties of the default speech acts made with the help of the sentence. This means that the relevant sentences will be taken to denote a set of input-output context pairs $\left\langle\mathrm{c}, \mathrm{C}^{\prime}\right\rangle$, where certain requirements concerning the public commitments of and the questions publicly asked by particular discourse agents are satisfied. The contextual presuppositions introduced by the relevant forms are captured in this system by introducing conditions on the input context $\mathrm{c}$. For formalizing the CCPs of Hungarian sentences containing ugye, we will rely on a system that takes its inspiration from Davis (2011). The parameters of the context that will be referred to in the discussion include the following:

- the concept of the Common Ground (Stalnaker 1978), abbreviated as CG, which refers to the set of propositions that the participants are jointly committed to,

- for each participant $x$, the set of Public Commitments of $x$ in context c, referred to as $\mathrm{PC}_{x}^{\mathrm{C}}$, which is the set of propositions that $x$ is publicly committed to in the context, but which are not (yet) joint commitments, following Gunlogson (2003) and Farkas and Bruce (2010),

- for each participant $x$, the set of Public Questions asked by $x$ in context C, referred to as $\mathrm{PQ}_{x}^{\mathrm{C}}$, which consists of question denotations (represented by sets of propositions, cf. Hamblin 1973), following Davis (2011),

- the semantic value of the sentence that was used to make the last question act by $x$ in context $\mathrm{C}, \mathrm{PQ}_{x}^{\mathrm{C}}[0]$,

- a set of discourse agents $\mathbb{A}$, among which the perspective center in context $\mathrm{C}$ will be referred to as $P^{\mathrm{C}}$, and the counterpart of the perspective center as $A \backslash\{P\}^{\mathrm{C}}$.

We will assume that assertions made by $x$ with the help of the declarative sentence $S$ change the context by adding the proposition $\varphi$, equivalent to the propositional content of $S$, to $\mathrm{PC}_{x}^{\mathrm{C}}$. $\varphi$ will become part of the CG if the interlocutor of $x$ also commits to it, either explicitly, or implicitly, by not objecting to it. (Cf. Farkas and Bruce 2010, for further discussion.)

Establishing $\mathrm{PQ}_{x}^{\mathrm{C}}$ for each participant results in a partition of the set of the Questions Under Discussion (QUD), which is the ordered set of the questions asked (by any participant) in the course of the discourse, which have not yet been answered (Roberts 2012). The reason why we consider it important to record who asked a particular question in the discourse, as opposed to Roberts (2012) and Farkas and Bruce (2010), is that this makes it possible to follow which participant bears the burden of having to provide an answer. ${ }^{16}$ Asking a question by participant $x$ thus results in the addition of a question denotation to $\mathrm{PQ}_{x}^{\mathrm{C}}$.

The fact that the identity of the participant whose input commitments ugye makes reference to changes across the sentence forms is accounted for by marking a participant $P$ in the set $\mathbb{A}$ as the perspective center (cf. Sect. 2 above). As discussed in the literature (McCready 2007; Stephenson 2005), the perspective center is the speaker as a default, but it is obligatorily shifted to the hearer in questions. In a particular case, the perspective center is identical to the participant whose PC or PQ

\footnotetext{
${ }^{16} \mathrm{Cf}$. Krifka (2001) on the properties of 'paired acts' consisting of initiating and responding acts.
} 
is updated in context $\mathrm{C}^{\prime}$ : it is the speaker if PC is updated, and the hearer if PQ is updated.

(14)-(15) below illustrate how the interpretation of a declarative form $S$-ugye , where the particle does not bear intonational marking, and a form $S$-ugye $\Lambda$, which consists of a declarative $S$ and an internal or final ugye bearing a rise-fall tone and is used to make a question act, are given in terms of CCPs in the framework outlined above. $\varphi$ stands for the propositional content of $S$.

$$
\begin{aligned}
& \llbracket \text { S-ugye } \rrbracket^{\mathbb{A}}=\left\{\left\langle\mathrm{C}, \mathrm{C}^{\prime}\right\rangle \mid \varphi \in \mathrm{PC}_{P}^{\mathrm{C}_{C}^{\prime}} \wedge \varphi \in \mathrm{PC}_{\mathbb{A} \backslash\{P\}^{\mathrm{C}}}^{\mathrm{C}}\right\} \\
& \llbracket S \text {-ugye } \wedge \rrbracket^{\mathbb{A}}=\left\{\left\langle\mathrm{C}, \mathrm{C}^{\prime}\right\rangle \mid \mathrm{PC}_{\mathbb{A} \backslash\{P\}}^{\mathrm{C}}{ }^{\mathrm{C}} \mathrm{C}[0]=\{\varphi, \neg \varphi\} \wedge \varphi \in \mathrm{PC}_{\mathbb{A} \backslash\{P\}}^{\mathrm{C}}\right\}
\end{aligned}
$$

In plain English, (14) expresses that given a set of discourse agents $\mathbb{A}$, the interpretation of an $S$-ugye declarative sentence is taken to be the set of input-output context pairs such that in the output context the public commitments of the perspective center (the speaker) are updated with the proposition $\varphi$, and that in the input context her counterpart (i.e. the complement of the set $\{\mathrm{P}\}$ with respect to A), the hearer, is committed to $\varphi$. (15) says that the interpretation of an $S$-ugye $\Lambda$ sentence containing an internalized tag is taken to be the set of input-output context pairs such that the output context involves an update of the public questions by the counterpart of the perspective center, the speaker (which amounts to the addition of the set $\{\varphi, \neg \varphi\}$ to it) and that in the input context the same participant is committed to $\varphi$. Note, importantly, that the last conjuncts in (14) and (15), which refer to a condition on input contexts, are identical, and state that $\varphi$ is an element of the set of propositions constituting the public commitments of the counterpart of the perspective center, which is the speaker in the case of assertions and the addressee in the case of questions. The above requirement on input contexts is thus the uniform contribution of ugye, without its intonation, which was argued for informally in the previous section.

\section{Conclusions and Open Issues}

The present paper investigated the interpretation of the Hungarian particle ugye, which can, modulo its prosodic realization, appear both as an internalized tag, contributing a biased question interpretation, and as a discourse particle contributing an "as we know" reading to declaratives. We provided an outline of a possible historical development from a tag-type use to a sentence internal use, in the course of which the contribution of intonation was separated from the contribution of ugye and the form itself lost its compositional interpretation. We then proposed a uniform formal account of its two synchronic uses in a dynamic semantic framework. Ugye was argued to contribute in all its uses a condition on input contexts, according to which the discourse agent who is the interlocutor of the default 
perspective center of the speech act at hand is committed to the propositional content of the sentence.

The assumption that ugye targets the "complement" of the perspective center $\mathbb{A} \backslash\{P\}^{\mathrm{C}}$ seems to successfully account for native speakers' intuitions about the contribution of the particle across different utterance types. There is one problem that the proposal raises, however. Since sensitivity to the complement of the perspective center has not been attributed to any expression in any language before, the question arises whether there is further evidence that this is a parameter of the context that operators can be sensitive to, or, assuming that perspective centers are parameters of Kaplanian contexts (Kaplan 1989), are we proposing "monster" operators in the Kaplanian sense ${ }^{17}$ The discussion of these implications will have to be left for a future occassion.

\section{References}

Abuczki, Ágnes. 2015. A multimodal discourse-pragmatic analysis of ugye ( 'is that so?'). Sprachtheorie und germanistische Linguistik 25 (1): 41-74.

Asher, Nicholas, and Brian Reese. 2007. Intonation and discourse: biased questions. Interdisciplinary Studies on Information Structure 8: 1-38.

Benkő, Loránd. 1995. Etymologisches Wörterbuch des Ungarischen II. Budapest: Akadémiai Kiadó.

Bylinina, Lisa, Eric McCready, and Yasutada Sudo. 2014. The landscape of perspective shifting. Pronouns in embedded contexts at the syntax-semantics interface. Tübingen, 7-9 November 2014.

Davis, Christopher. 2009. Decisions, dynamics and the Japanese Particle yo. Journal of Semantics 26: 329-366.

Davis, Christopher. 2011. Constraining interpretation: Sentence final particles in Japanese. $\mathrm{PhD}$ diss., University of Massachusetts, Amherst.

Eckardt, Regine. 2006. Meaning change in grammaticalization. Oxford: OUP.

Farkas, Donka F., and Kim Bruce. 2010. On reacting to assertions and polar questions. Journal of Semantics 27: 81-118.

Farkas, Donka F., and Floris Roelofsen. 2017. Division of labor in the interpretation of declaratives and interrogatives. Journal of Semantics 34: 237-289.

Fónagy, Iván, and Klára Magdics. 1967. A magyar beszéd dallama. Budapest: Akadémiai Kiadó.

Grice, Martine, D. Robert Ladd, and Amalia Arvaniti. 2000. On the place of phrase accents in intonational phonology. Phonology 17: 143-185.

Gunlogson, Christine. 2003. True to form. Rising and falling declaratives as questions in English. New York: Routledge.

Gunlogson, Christine. 2008. A question of commitment. Belgian Journal of Linguistics 22:101136.

Gutzmann, Daniel. 2015. Use-conditional meaning. Studies in multidimensional semantics. Oxford: Oxford University Press.

Gyuris, Beáta. 2009. Sentence-types, discourse particles, and intonation in Hungarian. In Proceedings of Sinn und Bedeutung, SinSpeC Volume 5, June 2009, vol. 13, ed. T. Solstad and A. Riester. Stuttgart: Stuttgart University.

\footnotetext{
${ }^{17} \mathrm{I}$ thank one of the anonymous reviewers of the paper for raising these important concerns.
} 
Gyuris, Beáta. 2017. New perspectives on bias in polar questions: A study of Hungarian -e. International Review of Pragmatics 9: 1-50.

H. Molnár, Ilona. 1968. A módosítószók mondattani arculatának kérdéséhez. Magyar Nyelv 55:357-361, 470-480.

Hamblin, Charles. 1973. Questions in Montague English. Foundations of Language 10: 41-53.

Kaplan, David. 1989. Demonstratives. In Themes from Kaplan, ed. J. Almog, J. Perry, and H. Wettstein. Oxford: Oxford University Press.

Károly, Sándor. 1962. A kijelentő, felkiáltó, óhajtó, felszólító és kérdő mondat. In A mai magyar nyelv rendszere, ed. J. Tompa. Budapest: Akadémiai Kiadó.

Kenesei, István, Robert Michael Vago, and Anna Fenyvesi. 1998. Hungarian. London: Routledge.

Keszler, Borbála. 2000. Magyar grammatika. Budapest: Nemzeti Tankönyvkiadó.

Kleiber, Judit, and Gábor Alberti. 2014. ReALIS: Discourse representation with a radically new ontology. In Complex visibles out there. Proceedings of the Olomouc linguistics colloquium 2014: Language use and linguistic structure, ed. L. Veselovská and M. Janebová. Olomouc: Palacký University.

Kornai, András, and László Kálmán. 1988. Hungarian sentence intonation. In Autosegmental studies in pitch accent, ed. H. van der Hulst, and N. Smith. Dordrecht: Foris.

Krifka, Manfred. 2001. Quantifying into question acts. Natural Language Semantics 9: 1-40.

Krifka, Manfred. 2017. Negated polarity questions as denegations of assertions. In Contrastiveness in information structure, alternatives and scalar implicatures, ed. F. Kiefer and C. Lee, 359398. Cham: Springer International Publishing Switzerland.

Kugler, Nóra. 1998. A partikula. Magyar Nyelvốr 122: 214-219.

Ladd, D. Robert. 1981. A first look at the semantics and pragmatics of negative questions and tag questions. CLS 17: 164-171.

Ladd, D. Robert. 1996. Intonational phonology. Cambridge: Cambridge University Press.

Lasersohn, Peter. 2005. Context dependence, disagreement, and predicates of personal taste. Linguistics and Philosophy 28: 643-686.

Mády, Katalin, and Ádám Szalontai. 2014. Where do questions begin?-phrase-initial boundary tones in Hungarian polar questions. Social and linguistic speech prosody. In Proceedings of the 7th international conference on speech prosody, ed. N. Campbell, D. Gibbon and D. Hirst. Dublin, Ireland: Trinity College.

Malamud, Sophia A., and Tamina Stephenson. 2015. Three ways to avoid commitments: Declarative force modifiers in the conversational scoreboard. Journal of Semantics 32: 275311.

McCready, Eric. 2007. Context shifting in questions and elsewhere In Proceedings of Sinn und Bedeutung 11, ed. E. Puig-Waldmüller. Barcelona: Universitat Pompeu Fabra.

Molnár, Cecília Sarolta. 2016. Ugye melyik szabály alól ne találnánk kivételt? Az ugye partikula előfordulása kiegészítendő kérdésekben. Jelentés és Nyelvhasználat 3: 151-167.

Oravecz, Csaba, Tamás Váradi, and Bálint Sass. 2014. The Hungarian Gigaword Corpus. In Proceedings of LREC 2014.

Péteri, Attila. 2002. Abtönungspartikeln im deutsch-ungarischen Sprachvergleich. Budapest: Asteriskos.

Reese, Brian. 2007. Bias in questions. PhD diss., University of Texas at Austin.

Roberts, Craige. 2012. Information structure in discourse: Towards an integrated formal theory of pragmatics. Semantics and Pragmatics 5: Article 6: 1-69.

Schirm, Anita. 2011. A diskurzusjelölők funkciói: a hát, az -e és a vajon elemek története és szinkrón státusza alapján. PhD diss., Szegedi Tudományegyetem, Szeged.

Stalnaker, Robert. 1978. Assertion. In Syntax and semantics 9: Pragmatics, ed. P. Cole. New York: Academic Press. 
Stephenson, Tamina. 2005. Assessor sensitivity: Epistemic modals and predicates of personal taste. In New work on modality, ed. J. Gajewski, V. Hacquard, B. Nickel and S. Yalcin.

Stephenson, Tamina. 2007. Towards a theory of subjective meaning. PhD diss., MIT.

Tonhauser, Judith, David Beaver, Craige Roberts, and Mandy Simons. 2013. Toward a taxonomy of projective content. Language 89: 66-109.

Varga, László. 2002. Intonation and stress. Evidence from Hungarian. Basingstoke: Palgrave Macmillan

Zimmermann, Malte. 2011. Discourse particles. In Semantics, vol. 2, ed. K. von Heusinger, C. Maienborn and P. Portner. Berlin: de Gruyter, 2012-2038. 